\title{
Symbolism and Propaganda Versus Cartographic Scientific Consistency - Three Maps by Pierre Duval, Stjepan Glavač and Johann Christoph Weigl
}

\author{
Sven LONČAR \\ University of Zagreb, Faculty of Humanities and Social Sciences, Ivana Lučića 3, 10000 Zagreb, Croatia \\ sloncar24@gmail.com
}

Abstract. The aim of this paper, based on three maps of the Croatian lands by Stjepan Glavač, Pierre Duval and Johann Christoph Weigl, is to show or rather prove the presence of propaganda messages in cartography as a scientific discipline. The maps were chosen because in research conducted to date, no propaganda elements conveying hidden messages in the area they depict have been identified. The maps reveal elements of propaganda which will be critically interpreted. In the conclusion, a short review of the paper is presented with all the maps and a personal opinion about the maps as propaganda media of that time.

Keywords: cartography, cartographic sources, propaganda, Croatian modern history, Croatian lands in the modern period, Croatian lands in the 16 th century

\section{Introduction}

Propaganda is a way of conveying messages to the public via mass media such as television, radio and the internet. ${ }^{1}$ However, bearing in mind the historical context in which propaganda develops, the definition given by Garth S. Jowett and Victoria O'Donnell is more accurate. In Propaganda \& Persuasion they describe propaganda as a deliberately caused perception of reality which achieves the propagandists' aims (Jowett and O'Donnell 2006, 1-3). ${ }^{2}$ Shaping and manipulation are present in cartography as well, which means that maps, besides being useful conveyers of information, can also be used as instruments for spreading propaganda (Boria 2008, 279). Propaganda has always been present in cartography. However, the interest of the scientific community in researching it only started relatively

\footnotetext{
1 "Propaganda", Proleksis enciklopedija - online edition. Miroslav Krleža Lexicographical Institute <http://proleksis.lzmk.hr/ 42767/> (accessed 29th January 2018).

${ }^{2}$ Quoted from: Kristy Littlehale. "Propaganda". Storyboard That. <http://www.storyboardthat.com/hr/articles/e/propaganda> (accessed 29 Jan 2018).
}

recently, especially in terms of the development of critical cartography, whose founder, John Brian Harley, made the first reflections on maps as media for displaying influence and power. This means that maps cannot be disconnected from the processes of the division of power where they were created, even though they are based on scientific practice (Harley 1988, 279).

The aim of this paper is to prove the presence of propaganda in three maps depicting the Croatian lands. The first map was made by Pierre Duval in 1663 (Mlinarić and Gregurović 2011, 354), the second by Stjepan Glavač in 1673, and the third by Johann Christoph Weigl in 1720. The basic research question, which will be answered in the conclusion, is whether any of the maps contains hidden propaganda. If so, how much propaganda is present and whether and to what extent can the maps be characterized as media for spreading propaganda messages?

\section{Propaganda in Cartography}

When considering the cartographic presentation of a certain country or area, we must remember that maps are in a sense 'texts' which speak about social and

KiG No. 33, Vol. 19, 2020 https://doi.org/10.32909/kg.19.33.2 - - 


\title{
Propaganda nasuprot kartografsko- znanstvenoj (ne)korektnosti - primjer karata Pierrea Duvala, Stjepana Glavača i Johanna Christopha Weigla
}

Sven LONČAR

\author{
Sveučilište u Zagrebu, Filozofski fakultet, Ivana Lučića 3, 10000 Zagreb
} sloncar24@gmail.com

\begin{abstract}
Sažetak. Cilj je ovoga rada, na temelju karata hrvatskih zemalja Stjepana Glavača, Pierrea Duvala i Johanna Christopha Weigla, prikazati, odnosno dokazati prisutnost propagande, to jest propagandnih poruka u kartografiji kao znanstvenoj disciplini. Razlog izbora navedenih karata leži u činjenici kako u njima, u dosadašnjem istraživanju, nisu uočeni propagandni elementi koji prenose skrivene poruke o području koje prikazuju. Na primjerima navedenih karata bit će predstavljeni elementi propagandnog sadř̌aja koji će se kritički interpretirati. Pritom će, u zaključku, biti iznesen kratki pregled sadržaja rada, kao i svih karata, te će se donijeti osobni sud o navedenim kartama kao svojevrsnim propagandnim medijima tadašnjeg vremena.
\end{abstract}

KIjučne riječi: kartografija, kartografski izvori, propaganda, hrvatska novovjekovna povijest, hrvatske zemlje u novom vijeku, hrvatske zemlje u 16. stoljeću

\section{Uvod}

Pod današnjim pojmom propagande obično se govori o svakom prenošenju poruka zainteresiranoj javnosti putem masovnih medija kao što su televizija, radio i Internet. ${ }^{1}$ Međutim, uzimajući u obzir povijesne kontekste u kojima se propaganda razvijala, bilo bi konkretnije i nadasve točnije navesti definiciju Gartha S. Jowetta i Victorije O'Donnell koji su u svojoj knjizi Propaganda i Persuasion propagandu opisali kao namjerno izazvano percipiranje stvarnosti s postizanjem određenog cilja kod propagandista (Jowett i O'Donnel 2006, 1-3.). ${ }^{2}$ Navedena oblikovanja i manipulacije prisutni su i u kartografiji, što znači da karta, osim što može poslužiti kao korisno sredstvo spoznaje, također može poslužiti i kao svojevrsni instrument za širenje neke određene vrste

\footnotetext{
${ }^{1}$ Propaganda. Proleksis enciklopedija - online izdanje. Leksikografski zavod Miroslav Krleža. http://proleksis.lzmk.hr/42767/ (pristupljeno 29. I. 2018.).

2 Citirano prema: Kristy Littlehale. „Propaganda“. Storyboard That. http://www.storyboardthat.com/hr/articles/e/propaganda (pristupljeno 29. I. 2018.).
}

propagande (Boria 2008, 279). Prisutnost propagande $u$ kartografiji može se primijetiti još od njezinih samih početaka, ali interes znanstvene zajednice za istraživanjem iste javio mnogo kasnije, pogotovo $u$ pogledu razvoja tzv. kritičke kartografije, čiji je osnivač John Brian Harley dao prva promišljanja o karti kao mediju iskazivanja nečijeg utjecaja i moći. To znači da karta ne može biti nepovezana s procesom raspodjele moći u kojem nastaje, bez obzira na to koliko se njezina izrada bazirala na znanstvenim uzusima (Harley 1988, 279).

Upravo je na temelju navedenog cilj ovog rada pokušati dokazati prisutnost propagande na trima kartama koje prikazuju hrvatske zemlje. Prva karta koja će se prikazati je karta Pierrea Duvala iz 1663. godine (Mlinarić i Gregurović 2011, 354), druga će biti ona Stjepana Glavača iz 1673. godine, a treća karta bit će ona Johanna Christopha Weigla iz 1720. godine. Temeljno istraživačko pitanje, čiji će odgovor biti ponuđen u zaključku, glasi skriva li bilo koja od spomenutih karata u sebi propagandu, odnosno propagandno djelovanje. Na kraju će biti donesen konačni sud o tome koliko je propaganda zastupljena unutar navedenih karata te mogu li se one $i$, na temelju navedenoga, $u$ 
political developments, and not mere 'figures' (Brković and Mlinarić 2013, 30). This raises the issue of the conflict between two branches of science: cartography and human geography (Crampton 2001, 236). The latter is extremely critical of the former, claiming that cartography lacks theorization, and is highly sceptical of applying technical approaches to geography. Throughout history, maps have been regarded as works of art, and their artistry encourages the researcher to investigate them further (Crampton 2009, 841). Thus maps have a double role: the aesthetic (artistic design) and the representative (faithful representation of a place). Several other types of dualism can be found in maps - subjective and objective representation of space, real and unreal geography, and mental figures versus mapping (Fuerst Bjeliš 2012, 296). ${ }^{3}$ With regard to many events in Croatian history, these contradictions are obviously present in the mapping of the Croatian lands. Thus, the history of the Croatian lands can be seen from several different viewpoints, all of which may be expressed on maps. In the past, maps were often considered the most accurate means of depicting a certain space. In the current postmodern period, this traditional view has been superseded (Harley 1989, 2).

In terms of the socio-anthropological context, each map conveys two perceptions of the space it deals with: the real and the imaginary (Brković and Mlinarić 2013, 30). By merging these two elements, the map conceals certain messages which are then transmitted to the public who analyse them, usually in a subjective way (Boria 2008, 282). This analysis transforms the map into a means of spreading propaganda. Here geocriticism, the science founded by the French theoretician Bertrand Westphal, advocates using interdisciplinarity to connect the spaces depicted by maps, making them a coherent "group of narratives", that is, a "representation network" of all media (Brković and Mlinarić 2013, 30-31). These narratives are very important in connecting the time and its influence on the space explored in cartography. However, here we encounter the problem of special heterogeneity based on space isotropy, the opposite of isotopy, which requires the geometrical equality of all points in space. In addition, there is the dichotomy of geographic visualization versus traditional cartography; unlike traditional cartography, which is based exclusively on examining maps at face value, geographic visualization implies map manipulation, especially through digital means (Crampton 2001, 244).

\footnotetext{
${ }^{3}$ Source: http://www.intechopen.com/books/cartography-a-toolfor-spatial-analysis/imaging-the-past-cartography-and-multicultural-realities-of-croatian-borderlands (accessed 30 Mar 2018).
}

However, the beginnings of geographic visualisation are found in geopolitical cartography, which tended to waive the educational aspect, a logical move since it was thought to lack a scientific approach. This opened the way to put theoretical conceptions into practice (Boria 2008, 283). These opportunities in cartography were passed on to geographers as well, who added other facets to their occupation, like political activism, leading them to exceed the limits of their field (Crampton 2009, 844-845). This automatically placed them between two concepts - maps and propaganda - and obliged them to map a space before someone else did so first.

\section{Elements of Propaganda in Pierre Duval's Map}

Pierre Duval's map, created in $1663,{ }^{4}$ is a typical example of the complexity of cartographic presentation, where the historic, conquest-related, real, imaginary and ideological aspects of mapping a certain territory literally collide (Mlinarić and Gregurović 2011, 354). So Duval divides Croatia in two parts: he labels the 'remains of the remains' (reliquiae reliquiarum) as 'Austrian Croatia' (Croatiel'Autriche), while the space between the River Una and the River Vrbas he calls 'Turkish Croatia' (Croatie av Turc). Such terminology, with the demarcation line, makes it clear that we are dealing with a division into two social groups: us, part of Europe, the Christians, and them, part of the Ottoman Empire, the Muslims. Duval's map also shows parts which belonged to the Croatian-Hungarian Kingdom but which had fallen under Ottoman rule. It is also important to note that the map precisely marks the demarcation line between the free parts of Austrian Croatia, and Turkish Croatia and Turkish Dalmatia. In terms of its content, this map could be considered geopolitical, since the demarcation line creates a clear distinction between the two spheres, and simplicity often provides the most information (Mlinarić and Gregurović 2011, 354; Boria $2008,282)$. But in the actual space, the territory was not divided as strictly as one might think; on the contrary, the people living in these areas often shared various ethnic, cultural and religious features (Mlinarić and Gregurović 2011, 355). This means that the distinction was imposed by the ruling class and predetermined political propaganda in the centres of the three imperial forces active in the Croatian lands: the Habsburg

\footnotetext{
${ }^{4}$ Source: Les confins des chrestiens et des Turcs en terre ferme, c'est-à-dire la Hongrie l'Esclavonie, la Croatie et la Dalmatie / par P. [Pierre] Du Val, Paris: Pierre DuVal, 1663, colour engraving; $37 \times 50 \mathrm{~cm}$ [scale $1: 1300$ 000] National and University Library in Zagreb.
}

KiG No. 33, Vol. 19, 2020, https://doi.org/10.32909/kg.19.33.2 
kolikoj mjeri okarakterizirati kao mediji za širenje propagandnih poruka.

\section{Propaganda u kartografiji}

Kad se govori o kartografskom prikazu određene zemlje ili njezinog kraja, mora se voditi računa da se pri analizi karte ona mora promatrati kao svojevrsni „tekst“ koji govori o društvenom i političkom razvoju nekog kraja, a ne kao običnu „sliku“ (Brković i Mlinarić 2013, 30). Navedena teza za sobom povlači sukob između dvije vrste znanosti: kartografije i društvene geografije (Crampton 2001, 236). Potonja je izrazito kritična prema kartografiji, tvrdeći kako kartografiji nedostaje teoretičnosti i pokazuje veliku skepsu prema primjeni tehnike u geografiji. Osim toga, prema karti se tijekom povijesti više odnosilo kao prema nekakvom umjetničkom djelu, a umjetnost je sredstvo koje potiče istraživača na daljnji proces istraživanja (Crampton 2009, 841). Time se stvara dvostruka uloga karte: estetska, koja se temelji na umjetničkom dizajnu i reprezentativna, koja se temelji na vjernom prikazivanju mjesta. Osim tog dualizma, kod karata se susreću još dva tipa - subjektivni i objektivni prikaz prostora, pojam stvarne i nestvarne geografije te mentalna slika nasuprot kartografskom prikazu (Fuerst Bjeliš 2012, 296). ${ }^{3}$ S obzirom na brojna zbivanja u hrvatskoj povijesti, navedene su kontradikcije itekako prisutne $u$ kartiranju hrvatskih zemalja. Tako se pomoću njih povijest hrvatskih zemalja može promatrati iz nekoliko različitih percepcija, a najbolje sredstvo za iskazivanje tih percepcija su upravo karte. Međutim, iako se karta u povijesti često prikazivala kao nekakvo najtočnije i najpreciznije sredstvo skiciranja određenog prostora, upravo je današnje razdoblje, odnosno razdoblje postmodernizma, ukinulo tu tradiciju (Harley 1989, 2).

Uzimajući u obzir socio-antropološki kontekst, svaka karta nosi u sebi dvije percepcije prostora koji obrađuje: stvarni i imaginarni (Brković i Mlinarić 2013, 30). Spajanjem tih dvaju elemenata karta u sebi skriva određenu poruku koja se zatim prenosi javnosti koja ju pak analizira obično na subjektivan način (Boria 2008, 282). Takva analiza kartu obično pretvara u sredstvo širenja propagande. Tu se javlja geokritika, znanost koju je utemeljio francuski teoretičar Bertrand Westphal, a koja zagovara da se

\footnotetext{
${ }^{3}$ Izvor: http://www.intechopen.com/books/cartography-atool-for-spatial-analysis/imaging-the-past-cartographyand-multicultural-realities-of-croatian-borderlands (pristupljeno 30. III. 2018.).
}

korištenjem interdisciplinarnosti prostori koje karta prikazuje zajedno povežu i time postanu jedna koherentna „skupina narativa“, odnosno „mreža reprezentacija“ svih medija (Brković i Mlinarić 2013, 3031). Navedeni narativi itekako su važni da bi se povezalo vrijeme i njegov utjecaj na prostor koji se u kartografiji istražuje. Međutim, tu se javlja problem prostorne heterogenosti koja se bazira na izotropiji prostora, što je suprotan pojam od izotopije koja nalaže geometrijsku jednakost svih točaka u prostoru. Tome se pridružuje i dihotomija pojmova geografske vizualizacije nasuprot tradicionalnoj kartografiji; za razliku od tradicionalne kartografije koja se bazira na isključivom promatranju karte „od oka“, geografska vizualizacija podrazumijeva i manipulaciju kartom, pogotovo na digitalni način (Crampton 2001, 244). Međutim, njezini počeci nalaze se upravo u geopolitičkoj kartografiji, za koju je bilo karakteristično da se odriče svoje obrazovne crte, što je inače bio i logičan potez s obzirom na činjenicu da joj se pripisivao manjak znanstvenosti u njezinom djelovanju, čime je ona bila slobodnija prenijeti svoje teorijske koncepcije u praksu (Boria 2008, 283). Te mogućnosti u kartografiji prenijele su se i na geografe koji su si uz svoje zanimanje pripisali i neko drugo, primjerice politički aktivizam, čime su počeli izlaziti iz svoje struke (Crampton 2009, 844-845). Time su automatski postali smješteni između dva koncepta - karte i propagande, zbog čega moraju kartirati prostor što je prije moguće, inače će netko drugi kartirati njih same te time obaviti njihov posao.

\section{Propagandni elementi na karti Pierrea Duvala}

Karta Les confins des chrestiens et des Turcs en terre ferme Pierrea Duvala ${ }^{4}$, nastala 1663. godine, tipičan je primjer kompleksnosti kartografskog prikaza, unutar kojeg se doslovce sudaraju povijesni, osvajački, stvarni, imaginarni i ideološki aspekti kartiranja određenog teritorija (Mlinarić i Gregurović 2011, 354). Duval tako Hrvatsku dijeli na dva dijela: tzv. „ostatke ostataka“ (reliquiae reliquiarum) označava kao „austrijsku Hrvatsku“ (Croatie l'Autriche), dok prostor između rijeka Une i Vrbasa naziva "turskom Hrvatskom“ (Croatie av Turc). Takva terminologija, uz postavljanje crte razgraničenja, jasno daje do znanja da se radi o podjeli

\footnotetext{
${ }^{4}$ Izvor: Les confins des chrestiens et des Turcs en terre ferme, c'est-à-dire la Hongrie l'Esclavonie, la Croatie et la Dalmatie / par P. [Pierre] Du Val, Paris: Pierre DuVal, 1663., bakrorez, koloriran; $37 \times 50 \mathrm{~cm}$ [mjerilo $1: 1300$ 000] Nacionalna i sveučilišna knjižnica u Zagrebu.
} 


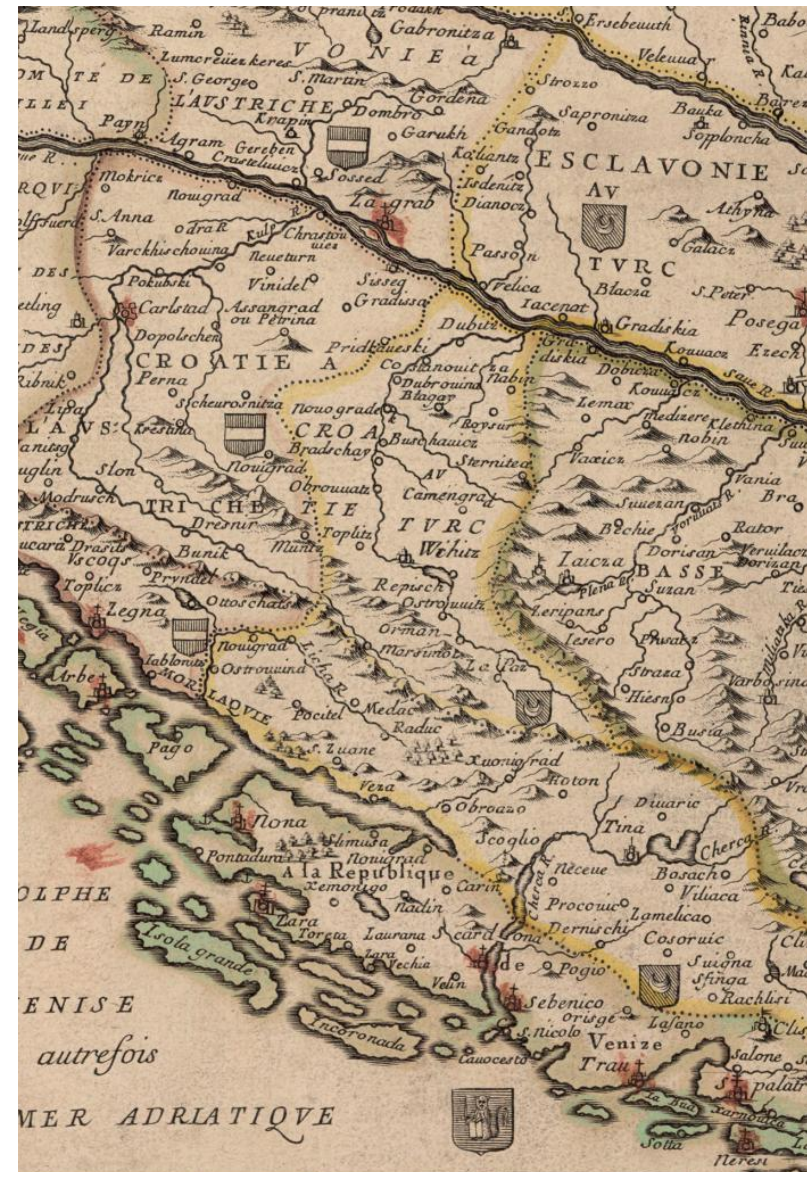

Fig. 1 Detail of Duval's map which clearly shows the division of the Croatian lands (Pierre Duval: Les confins des chrestiens et des Turcs en terre ferme, 1663).

Slika 1. Detalj s Duvalove karte koji jasno prikazuje podijeljenost hrvatskih zemalja (Pierre Duval, Les confins des chrestiens et des Turcs en terre ferme, 1663).

Monarchy, the Venetian Republic and the Ottoman Empire. The distinction is especially obvious in the description of Dubrovnik, which was marked as a part of the Roman Catholic world (us), but due to the vicinity of the border and foreign policy, it is given the same colour as its eastern neighbour, Bosnian Sandzak (Brković and Mlinarić 2013, 44). However, the mapping of the Croatian area was also greatly influenced by the different social and historical contexts, familiarity with the areas depicted, and map-making techniques of the three powers (Mlinarić and Gregurović 2011, 355).

Duval's map clearly shows the Croatian lands divided between the Catholic and Ottoman worlds. The division can be seen in the coats-of-arms placed on the map; the Croatian lands which belonged to the Habsburg Monarchy have the Austrian coat-of-arms, while those under the Ottoman Empire have a crescent and a star (Figure 1) (Mlinarić and Gregurović 2011, 354). At first sight, the map does not seem to convey any socio-integrative propaganda. However, a closer look reveals certain details with hidden propaganda messages.

Duval's map also divides the Christian world from the Turkish using colours (Mlinarić and Gregurović 2011, 354). This is defined using coats-of-arms, primarily those of the Habsburgs and the Ottomans. However, other coats-of-arms can be found, for example the Dalmatian one (Figure 2). Duval made a double demarcation using dotted lines shaded with yellow or gold to divide the coastal part of Dalmatia from its hinterland, and the Dalmatian hinterland from Bosnia and Herzegovina (Figure 3). Here we are obviously dealing with spatial duality, but the question is why Duval decided on such a move. The answer may lie in the cartographer's personal perception (Harley 1989, 287). However, since the map was created in 1663, a full eight years before the end of the Candian War and the recognition of the 'old legacy', better known as the Linea Nani, Duval's double demarcation of the Habsburg-Ottoman border won the day (Valentić et al. 2005, 124-125).

What is also interesting on this map is the depiction of countries not mentioned in the map title: Serbia (Servie) and Albania (Albanie). Apart from their topography, the following can be detected: in the depiction of Serbia there are no coats-of-arms which define its political and cultural affiliation, and this presents a certain dilemma, as Serbia was under the Ottoman Empire at the time (Figure 4). Albania has a coat-of-arms with a crescent, which suggests it is situated within the Ottoman cultural reach (Figure 5). It is also interesting that there is no coat-of-arms of the Republic of Dubrovnik, probably because it was a less important political actor than the Habsburg Monarchy or Ottoman Empire (Brković and Mlinarić 2013, 43). The reason for such an omission, as in the previous case of the double demarcation of Dalmatia, probably lies in the author's personal perception, but he may also have been required to show the authority of the great powers over certain areas of interest, which Serbia at that time obviously was not (Fürst-Bjeliš and Zupanc 2007, 9).

\section{Elements of Propaganda in the Map by Stjepan Glavač}

The 1673 map by Stjepan Glavač ${ }^{5}$ went even further in showing exclusively the areas which remained

\footnotetext{
${ }^{5}$ Source: Nova hactenus editarum mendis expurgatis ac multis quae omissa erant additis accurate concinnata partium Regni Sclavoniae et Croatiae a Christianitate etiamnum possessarum confiniumque descriptio, per Stephanum Glavach. Varasdiensem, 1673 , copy; $83 \times 81 \mathrm{~cm}$, folded to $23 \times 32 \mathrm{~cm}$. [scale: $\mathrm{c}$. 1:250 000], National and University Library in Zagreb.
}

KiG No. 33, Vol. 19, 2020, https://doi.org/10.32909/kg.19.33.2 


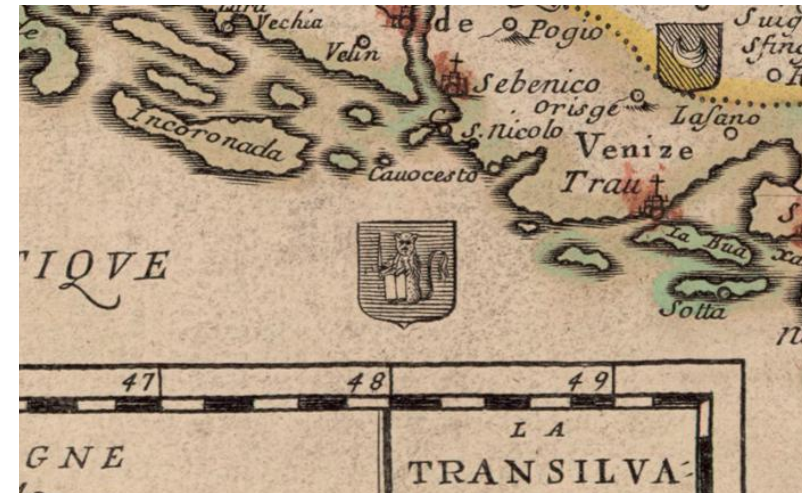

Slika 2. Prikaz dalmatinskog grba blizu dalmatinske obale (Pierre Duval: Les confins des chrestiens et des Turcs en terre ferme, 1663 , isječak).

Fig. 2 Dalmatian coat-of-arms near the Dalmatian coast (Pierre Duval: Les confins des chrestiens et des Turcs en terre ferme, 1663, detail).

na dva društva: mi kao dio Europe, odnosno kršćani i oni (Drugi) kao dio Osmanskog Carstva, odnosno muslimani. Duvalova karta prikazuje i one krajeve koji su nekad bili u sastavu Hrvatsko-Ugarskog Kraljevstva, a u navedeno su vrijeme bili pod osmanskom vlašću. Također je važno napomenuti kako navedena karta koncizno označava prethodno spomenutu crtu razgraničenja između slobodnih dijelova zemalja (tzv. „austrijska Hrvatska") i onih krajeva pod turskom vlašću (tzv. „turska Hrvatska“ i ,turska Dalmacija“). Međutim, po naglašavanju sadržaja ta bi karta više spadala pod geopolitičku kartu budući da povlačenjem granične crte stvara jasnu distinkciju između dva svijeta - kršćanskog i osmanskog, a upravo je jednostavnost ta koja može dati najviše informacija na karti (Mlinarić i Gregurović 2011, 354; Boria 2008, 282). Pri tome je važno napomenuti i kako navedene granice u stvarnom prostoru nisu toliko strogo dijelile teritorij kao što se misli naprotiv, stanovnici koji su živjeli na navedenim područjima često su znali dijeliti razna etnička, odnosno kulturna i konfesionalna obilježja (Mlinarić i Gregurović 2011, 355). To znači da je diferencijacija na tadašnjim kartama, pa i na ovoj, bila nametnuta od strane vladajuće klase i njihove unaprijed zacrtane političke propagande koja je u ono vrijeme bila aktualna u središtima triju imperijalističkih sila koje su djelovale na području hrvatskih zemalja: Habsburške Monarhije, Mletačke Republike i Osmanskog Carstva. Ta se diferencijacija pogotovo ističe u prikazu Dubrovnika koji je obilježen kao dio katoličke ekumene (mi), ali zbog blizine granice, kao i vanjske politike, označen je istom bojom kao i njegov istočni susjed Bosanski sandžak (Brković i Mlinarić 2013, 44). Međutim, osim tih diferencijacija, na kartiranje hrvatskih prostora uvelike su

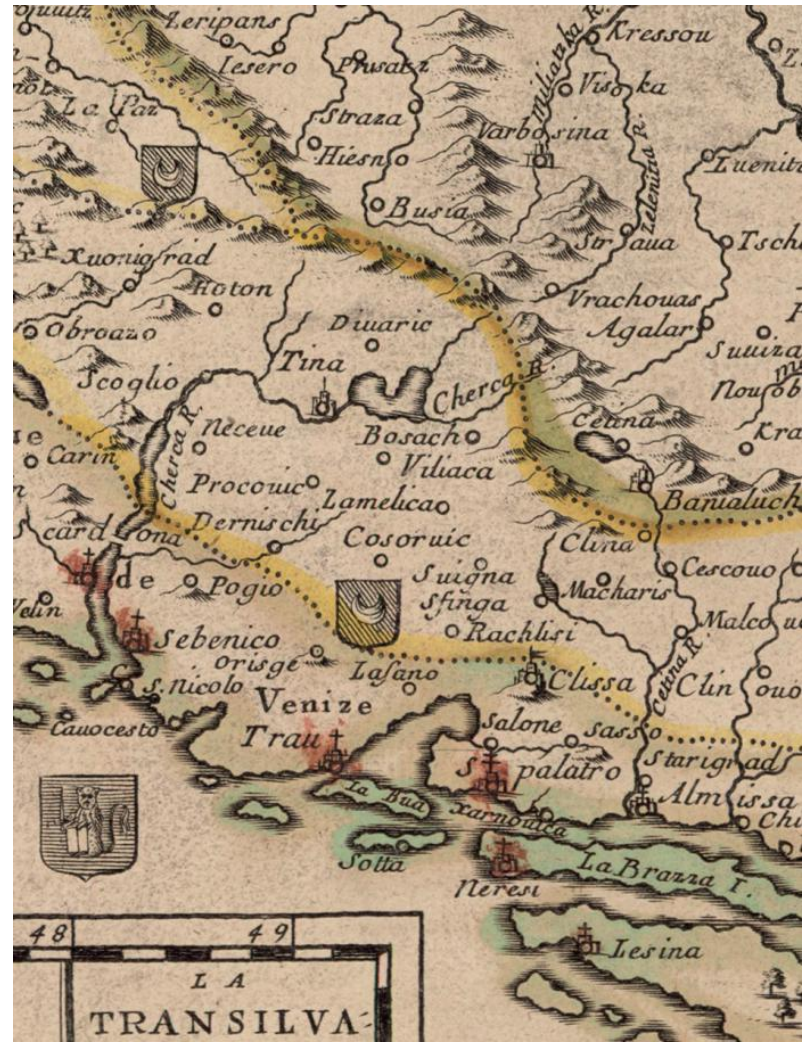

Slika 3. Dvostruko razgraničenje Dalmacije (Pierre Duval: Les confins des chrestiens et des Turcs en terre ferme, 1663 , isječak).

Fig. 3 Double demarcation of Dalmatia (Pierre Duval: Les confins des chrestiens et des Turcs en terre ferme, 1663, detail).

utjecali različiti društveni i povijesni konteksti, kao i poznavanje kraja te tehnika izrade karata u navedenim silama (Mlinarić i Gregurović 2011, 355).

Na početku je spomenuto kako Duvalova karta jasno prikazuje hrvatske zemlje podijeljene između kršćanskog i osmanskog svijeta. Navedena se podjela može vidjeti u obliku grbova koji su postavljeni na karti; hrvatske zemlje koje su u sastavu Habsburške Monarhije, označene su austrijskim grbom, dok su one pod osmanskom vlašću označene polumjesecom i zvijezdom (slika 1) (Mlinarić i Gregurović 2011, 354). Ta karta na prvi pogled ne prenosi nikakvu društveno-integrativnu propagandu koja je inače prisutna $u$ kartografiji, ali detaljnijim pregledom uočeni su određeni detalji pod kojima ova karta ipak skriva neke propagandne poruke.

Duvalova karta kršćanski i turski svijet, osim graničnim crtama, razdvaja i bojama, stvarajući time jasnu distinkciju između „nas“, Europljana i kršćana, i „,njih“, Osmanlija i muslimana (Mlinarić i Gregurović 2011, 354). Navedena distinkcija pobliže je označena grbovima, u prvom redu habsburškim i osmanskim, ali isto tako na karti se mogu pronaći i drugi grbovi, primjerice dalmatinski (slika 2). Isto tako može se primijetiti kako 


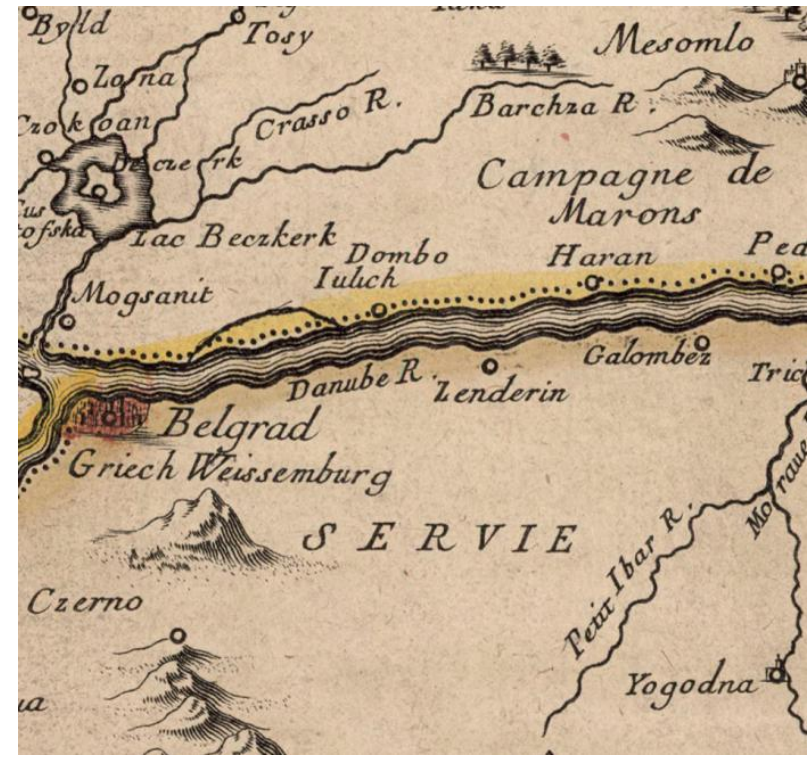

Fig. 4 Representation of Serbia without a related coat-ofarms (Pierre Duval: Les confins des chrestiens et des Turcs en terre ferme, 1663, detail).

Slika 4. Prikaz Srbije bez pripadajućeg grba (Pierre Duval Les confins des chrestiens et des Turcs en terre ferme, 1663 , isječak).

part of Croatia after the Ottoman and Venetian conquests, so that the Kvarner Littoral, Dalmatia, Lika, Slavonia and Krbava are completely left out, obviously following Duval and his classification, but in a more radical way (Marković 1993, 184).

Glavač's map shows the Croatian lands known to Glavač, that is, those not conquered by the Ottomans, and includes all the toponyms found there. However, it also shows some countries which were not then part of Croatia, for example, part of southwestern Hungary, which was conquered and came under the Ottoman Empire, (Pars Ungariae Turcis Subdita; Figure 6). Next to the caption there is a portrait of Nikola Zrinski, with a note that he lost 700 soldiers in the defence of Hungary on 4 May 1660, the year of the fall of Velika Kaniža. Another year, 1664, is also mentioned. That was when Zrinski was killed while hunting in the woods of Kuršanečki Lug near Čakovec (Valentić et al. 2005, 136).

Glavač stated in the map dedication to the Bishop of Zagreb, Martin Borković, that he had paid special attention to naming all the places he found historically important (Marković 1993, 186-191). So why did he decide to depict the part of Hungary under the Ottoman Empire, if the map (according to its title) covered only the Croatian lands which were not under Ottoman rule?

The reason lies in the map itself. Glavač stated in his dedication that he regretted that all previous maps of the Croatian lands were superficial, while maps of the surrounding countries were far more detailed (Marković 1993, 186). It is also important to mention that Glavač had connections with commanding officers in Ogulin Fort, who had complained to him about shortcomings in earlier maps. However, this argument is too weak to prove why Glavač decided to depict that part of Hungary. Perhaps he wanted to show the 'us' and 'them' state of affairs, as Duval had done earlier (Mlinarić and Gregurović 2011, 354). However, a new question then arises: why did Glavač decide to show only the parts of the Croatian lands not under the Ottoman Empire, while Duval showed the Habsburg, Venetian and Ottoman parts? In the dedication, Glavač claims he was guided by patriotism and his country's strategic needs (Marković 1993, 186). However, judging by the map's content, patriotism seems to have played only a small role in the map-making process, while a strategic aim (the defence of the remaining parts of the Croatian lands from Ottoman invasion) prevailed. In addition, Glavač mapped the areas that he was familiar with thoroughly, and those he was less familiar with in less detail or not at all.

The motif of the Croatian coat-of-arms situated in the area of contemporary Kordun, relatively near Steničnjak (Szteninszacak; Figure 7), is also interesting. In contrast to the previous motif, Glavaš probably recognized the historical importance of the location - this is where the last separate Croatian Parliament south of Sava was held in $1556^{6}$. Above the Croatian coat of arms, one can read uastatus hic totus tractus, i.e. the entire area devastated, with year 1548 appearing below the coat of arms. This is consistent with the historical fact that the Turks devastated the entire area around Topusko in 1548. This can be understood as a patriotic gesture on Glavač's part, a novelty in the cartography of that period, since up to the second half of the 20th century, maps were produced for military-political use rather than for the general public (Crampton 2001, 237). The Croatian and Slavonian coats-of-arms can also be seen on the map, with information on the Ottoman conquest of Velika in 1544 (Figure 9), although Slavonia was still under Ottoman occupation. In the bottom section of the map, the Dalmatian coat-of-arms can be seen as well (Figure 10) in the area of present-day Lika, near Jesenica Fort (Arx). It is clear that Glavač was informed about the historical

\footnotetext{
${ }^{6}$ Sabor Kraljevina Dalmacije, Hrvatske i Slavonije. ARHINET National archives information system.

$<$ http://arhinet.arhiv.hr/details.aspx?ItemId=3_8013> (accessed $5 \mathrm{Jul}$ 2018).
}

KiG No. 33, Vol. 19, 2020, https://doi.org/10.32909/kg.19.33.2 


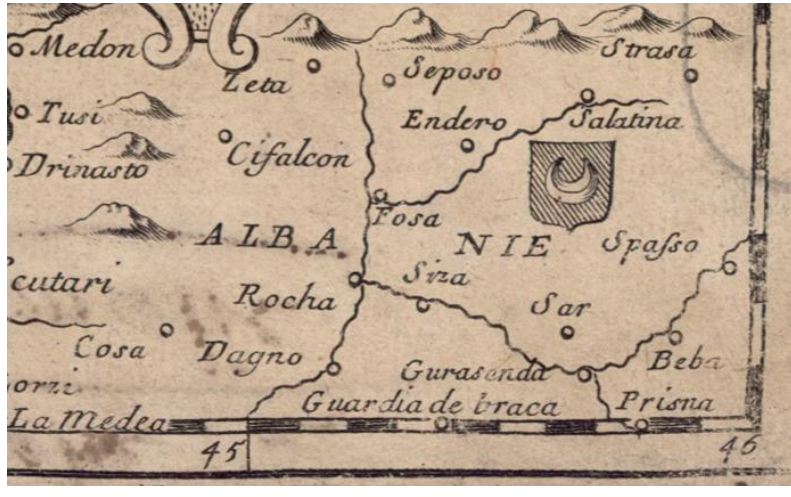

Slika 5. Prikaz Albanije s pripadajućim grbom (Pierre Duval Les confins des chrestiens et des Turcs en terre ferme, 1663 , isječak).

Fig. 5 Representation of Albania with a related coat-of-arms (Pierre Duval: Les confins des chrestiens et des Turcs en terre ferme, 1663, detail).

je Duval na području Dalmacije napravio dvostruko razgraničenje tako što je isprekidanim crtama osjenčanim žutom ili zlatnom bojom odvojio priobalni dio Dalmacije od njezinog zaleđa, kao i zaleđe Dalmacije od Bosne i Hercegovine (slika 3). Ovdje je evidentno da se radi o dvojnosti prostora po prethodno spomenutoj distinkciji „mi“ i „oni“, ali postavlja se pitanje koji je točno bio razlog da se Duval odlučio na takav potez? Odgovor na to pitanje mogla bi biti osobna percepcija samog kartografa (Harley 1989, 287), međutim kako je karta nastala 1663. godine, dakle punih osam godina prije završetka Kandijskog rata i priznavanja tzv. stare stečevine, poznatije kao Linea Nani, Duvalovo dvostruko razdvajanje habsburško-osmanske granice ovdje je dobilo svoj argument (Valentić i dr. 2005, 124-125).

Ono što je također zanimljivo na toj karti je i prikaz onih zemalja koje nisu spomenute u naslovu karte, a riječ je o Srbiji (Servie) i Albaniji (Albanie). Osim njihova topografskog prikaza uočava se i sljedeće: kod prikaza Srbije nema prikaza grba kojim je određena njezina politička i kulturalna pripadnost, što predstavlja popriličnu dilemu s obzirom na činjenicu da je Srbija u navedenom periodu bila pod osmanskom vlašću (slika 4), dok se u slučaju Albanije uočava prikaz grba s polumjesecom, što sugerira činjenicu da se ona nalazi u islamskom, odnosno osmanskom kulturnom krugu (slika 5). Također, zanimljivo je da na toj karti nema ni grbovnog prikaza Dubrovačke Republike; međutim, ova je tvrdnja potkrijepljena činjenicom da je Dubrovačka Republika bila manje važan politički faktor od Habsburške Monarhije i Osmanskog Carstva (Brković i Mlinarić 2013, 43). Razlog za takvu distinkciju nalazi se, kao i u prethodnom slučaju s dvostrukim razgraničenjem Dalmacije (autorova osobna percepcija), međutim također se može raditi i o

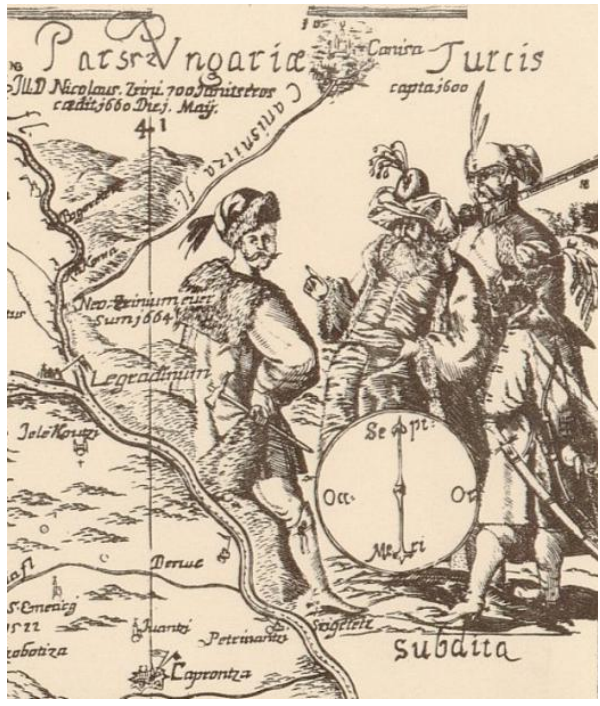

Slika 6. Prikaz dijela Ugarske pod osmanskom vlašću (Stjepan Glavač: Nova hactenus editarum mendis expurgatis, 1673 , isječak).

Fig. 6 Depiction of part of Hungary under the Ottoman Empire (Stjepan Glavač: Nova hactenus editarum mendis expurgatis, 1673, detail).

dokazivanju legitimacije velikih sila nad određenim interesnim područjima, što Srbija očito nije bila u ono vrijeme (Fürst-Bjeliš i Zupanc 2007, 9).

\section{Propagandni elementi na karti Stjepana Glavača}

Karta Stjepana Glavača iz 1673. godine $e^{5}$ otišla je još dalje prikazujući isključivo one krajeve koji su ostali u sastavu Hrvatske nakon osmanskih i mletačkih osvajanja, pri čemu je u svojem prikazu u potpunosti izostavila Kvarnersko primorje, Dalmaciju, Liku, Slavoniju i Krbavu. Ovdje se jasno vidi utjecaj Duvala i njegove prethodno spomenute podjele, ali na još radikalniji način time što je Dalmacija u potpunosti izostavljena u prikazu (Marković 1993, 184).

Glavačeva karta tako prikazuje one hrvatske zemlje koje je Glavač poznavao, odnosno hrvatske zemlje koje Osmanlije nisu osvojile i na njoj navodi sve toponime koji su tamo bili smješteni. Međutim, karta prikazuje i neke zemlje koje nisu sačinjavale dio tadašnje Hrvatske, a riječ je o dijelu jugozapadne Ugarske, za koju uz naslov napominje kako se radi o dijelu Ugarske koji je pod osmanskom vlašću (slika 6). Uz naziv se

\footnotetext{
${ }^{5}$ Izvor: Nova hactenus editarum mendis expurgatis ac multis quae omissa erant additis accurate concinnata partium Regni Sclavoniae et Croatiae a Christianitate etiamnum possessarum confiniumque descriptio, per Stephanum Glavach. Varasdiensem, 1673 , kopija, $83 \times 81 \mathrm{~cm}$, presavijena na $23 \times 32 \mathrm{~cm}$. [mjerilo oko 1:250 000], Nacionalna i sveučilišna knjižnica u Zagrebu.
} 


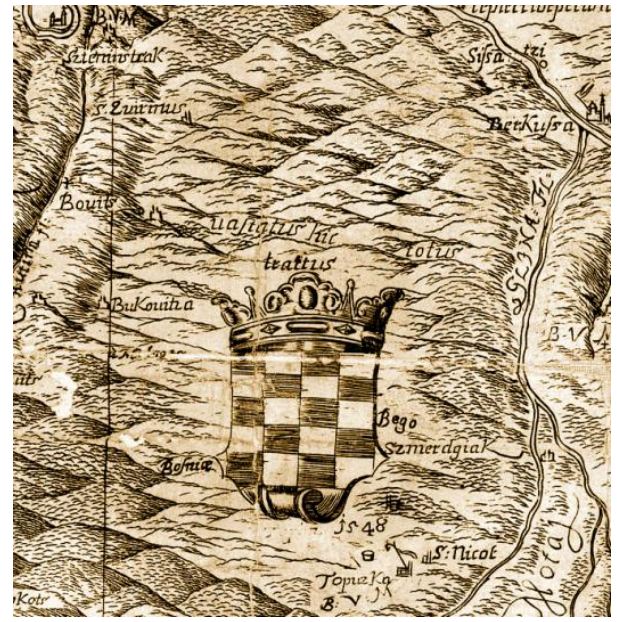

Fig. 7 Depiction of Croatian coat-of-arms and Steničnjak (Stjepan Glavač: Nova hactenus editarum mendis expurgatis, 1673, detail).

Slika 7. Prikaz hrvatskog grba i Steničnjaka

(Stjepan Glavač: Nova hactenus editarum mendis expurgatis, 1673, isječak).

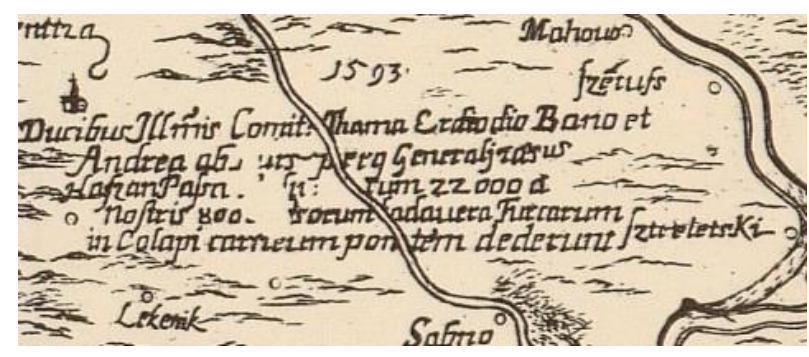

Fig. 8 Part of the map showing the description of the battle near Sisak in 1593 (Stjepan Glavač: Nova hactenus editarum mendis expurgatis, 1673).

Slika 8. Dio karte koji prikazuje opis bitke kod Siska 1593. (Stjepan Glavač: Nova hactenus editarum mendis expurgatis, 1673 , isječak).

development of Dalmatia, which in ancient times extended from the River Raša to Lješ in present-day Albania, with its eastern border near the river's source (Matijašić 2009, 185). This accounts for the positioning of its coat-of arms.

As far as the toponyms are concerned, they are written according to the ambivalent principle: the larger, more important places are written in the Latin version, while the smaller ones are in the Croatian version (Marković 1993, 194). The reason for Glavač's decision is very simple - Latin was the most widespread language in Europe at that time. Glavač also recorded in Latin some of the most important battles between the Croats and the Ottomans. Zagreb (Zagrabia) stands out, precisely situated between Mt. Medvednica and the River Sava (Figure 11), but it is interesting that its name is not as emphasized as some place-names in presentday Croatian Zagorje. Some were the sites of important battles with the Ottomans, for example Petrinja (Figure
12). This does not really fit with Harley's concept of undermining social structures, usually shown on maps below abstract instruments like scales or grids (Harley $1989,5)$, since this map had a primarily military, geostrategic purpose (Marković 1993, 186) and did not include elements suggesting the hierarchization of the society it represented (Harley 1989, 6).

\section{Elements of Propaganda on J. C. Weigl's Map}

Weigl's map, created in 1720, covers an even bigger area than Duval's and includes the Danube region, Pannonia, Moesia (present-day Serbia and northern Bulgaria), Dacia (modern-day Romania), Thrace (modernday southern Bulgaria) and Macedonia and Thessaly (modern-day northern Greece). ${ }^{7}$ The Croatian lands are rather clumsily depicted and seem squashed in comparison with Dacia, Moesia, Thrace, Macedonia and Thessaly. The toponymy is more concentrated in south Dalmatia, while the northern areas are sparsely marked. It is also interesting that the mountains in Gorski Kotar, Istria, the Croatian Littoral, Lika and Dalmatian Zagora are not depicted, while Bosnia is only partly correctly shown. There is not even a topographic description of Zagreb, while the River Sava is labelled as 'Pliny's Sava' (Savus A. Plinio). Sisak is described as Quadramtum Segestica ins. et urbs. However, near Vinkovci one can see the representation of a battle in the shape of two black crossed swords,

\footnotetext{
Source: Regiones Danubianae, Pannoniae, Dacia, Moesiae cum Vicino Illyrico, colour engraving; $39 \times 31 \mathrm{~cm}$ [scale unspecified], Christoph Weigelii. Norimbergae: Christoph Weigelii, [1720]. National and University Library in Zagreb.
}

KiG No. 33, Vol. 19, 2020, https://doi.org/10.32909/kg.19.33.2 - - 


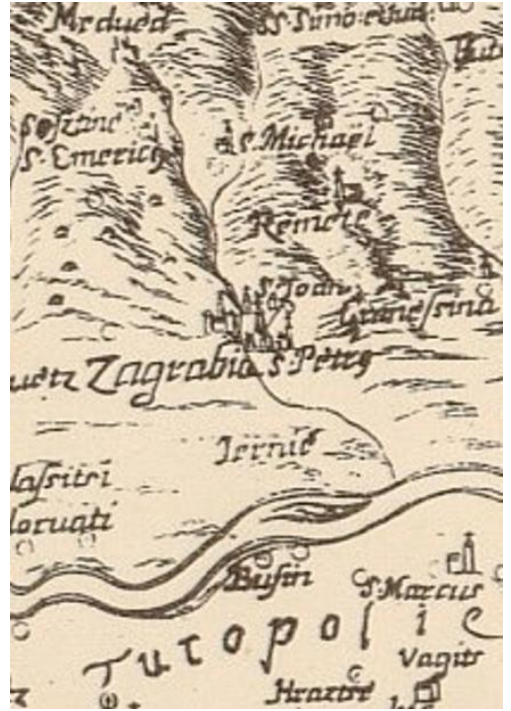

Slika 11. Položaj Zagreba (Stjepan Glavač: Nova hactenus editarum mendis expurgatis, 1673, isječak).

Fig. 11 The position of Zagreb (Stjepan Glavač: Nova hactenus editarum mendis expurgatis, 1673, detail).

nalazi portret Nikole Zrinskog uz koji stoji bilješka da je izgubio 700 vojnika pri obrani Ugarske 4. svibnja 1660. (pad Velike Kaniže) te pogibija Zrinskoga 1664. kao posljedica lova kod Kuršanečkog luga kraj Čakovca (Valentić i dr. 2005, 136).

Glavač je u posveti karte, namijenjenoj tadašnjem zagrebačkom biskupu Martinu Borkoviću, izjavio kako je pri izradi karte posebnu pažnju posvetio navođenju svih mjesta za koja je smatrao da su povijesno važna (Marković 1993, 186-191). Međutim, ta izjava sa sobom povlači pitanje: zašto se odlučio za prikaz dijela Ugarske pod osmanskom vlašću, ako karta prema naslovu obuhvaća samo hrvatske zemlje koje nisu pod osmanskom vlašću?

Razlog se nalazi na samoj karti. Glavač je u posveti istaknuo kako je bio razočaran zbog površne izradbe svih dotadašnjih karata koje su prikazivale hrvatske zemlje, dok su karte susjednih zemalja bile daleko preglednije (Marković 1993, 186). Također je važno napomenuti kako je Glavač pri izradi svoje karte bio povezan s vojnim zapovjednicima u ogulinskoj tvrđavi koji su ga upozorili na nedostatke pri prethodnim kartiranjima hrvatskih i susjednih zemalja, ali je taj argument preslab da bi dokazao razlog zašto se Glavač odlučio na prikaz baš tog dijela Ugarske. $S$ druge strane, moguće je da se ovdje radi, kao i kod Duvalove karte Hrvatske, o procesu odrugotvorenja po principu mi-oni (Mlinarić i Gregurović 2011, 354), što pojašnjava i spomenuti prikaz Ugarske i naziv karte. Međutim, ovdje se otvara novo pitanje: zašto se Glavač pri izradi karte odlučio prikazati samo dijelove hrvatskih zemalja izvan osmanske vlasti, za razliku od Duvala koji je prikazao i njihov

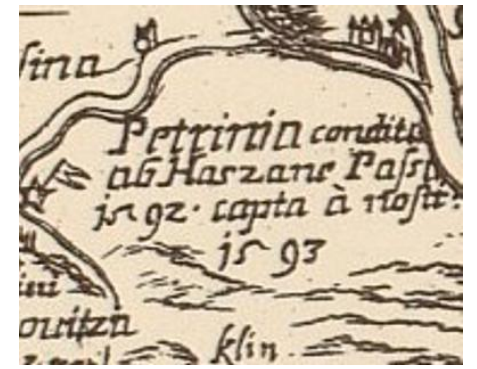

Slika 12. Prikaz Petrinje s podacima o bitci iz 1592. godine (Stjepan Glavač: Nova hactenus editarum mendis expurgatis, 1673, isječak).

Fig. 12 Representation of Petrinja with information on the battle of 1592 (Stjepan Glavač: Nova hactenus editarum mendis expurgatis, 1673, detail).

habsburški, mletački i osmanski dio? U posveti Glavač tvrdi kako su mu niti vodilje za izradu karte bili domoljublje i strateške potrebe zemlje (Marković 1993, 186), ali sudeći prema samom sadržaju karte domoljublje je igralo malu ulogu u procesu izrade te je karta imala više strateški značaj od onog domoljubnog. Tome ide u prilog činjenica da je Glavač detaljnije kartirao one krajeve koje je poznavao, dok je one njemu nepoznate slabije kartirao ili u potpunosti izostavio.

Zanimljiv je i motiv hrvatskog grba koji je smješten na područje današnjeg Korduna, relativno blizu mjesta Steničnjak (Szteninszacak; slika 7). Za razliku od prethodnog motiva, Glavač je vjerojatno prepoznao povijesnu važnost navedenog mjesta - naime, tamo je 1556. održan posljednji odvojeni Hrvatski sabor južno od Save. ${ }^{6}$ Iznad hrvatskoga grba možemo pročitati uastatus hic totus tractus, tj. opustošen ovaj cijeli kraj, a ispod grba stoji godina 1548. To je u skladu s povijesnom činjenicom da su Turci 1548. poharali cijeli kraj oko Topuskoga. Time se taj prikaz može protumačiti kao Glavačev domoljubni čin, što je inače novitet u tadašnjoj kartografiji budući da je kartografija do polovice 20. st. bila više orijentirana prema struci, a manje prema javnosti (Crampton 2001, 237). Osim hrvatskog, na karti se može vidjeti i prikaz slavonskog grba s podatkom o osmanskom zauzeću Velike 1544. godine (slika 9), iako je Slavonija još uvijek bila pod osmanskom okupacijom, a razlog za njezin prikaz može se protumačiti na isti način kao i u slučaju prikaza hrvatskog grba. Na najdonjem dijelu karte također se može vidjeti i dalmatinski grb (slika 10) koji je smješten na području današnje Like, točnije pored mjesta, odnosno utvrde Jesenica. Iz tog pozicioniranja jasno se vidi da

\footnotetext{
${ }^{6}$ Izvor: Sabor Kraljevina Dalmacije, Hrvatske i Slavonije. ARHINET - Nacionalni arhivski informacijski sustav.

$<$ http://arhinet.arhiv.hr/details.aspx?ItemId=3_8013> (pristupljeno 5. VII. 2018.).
} 


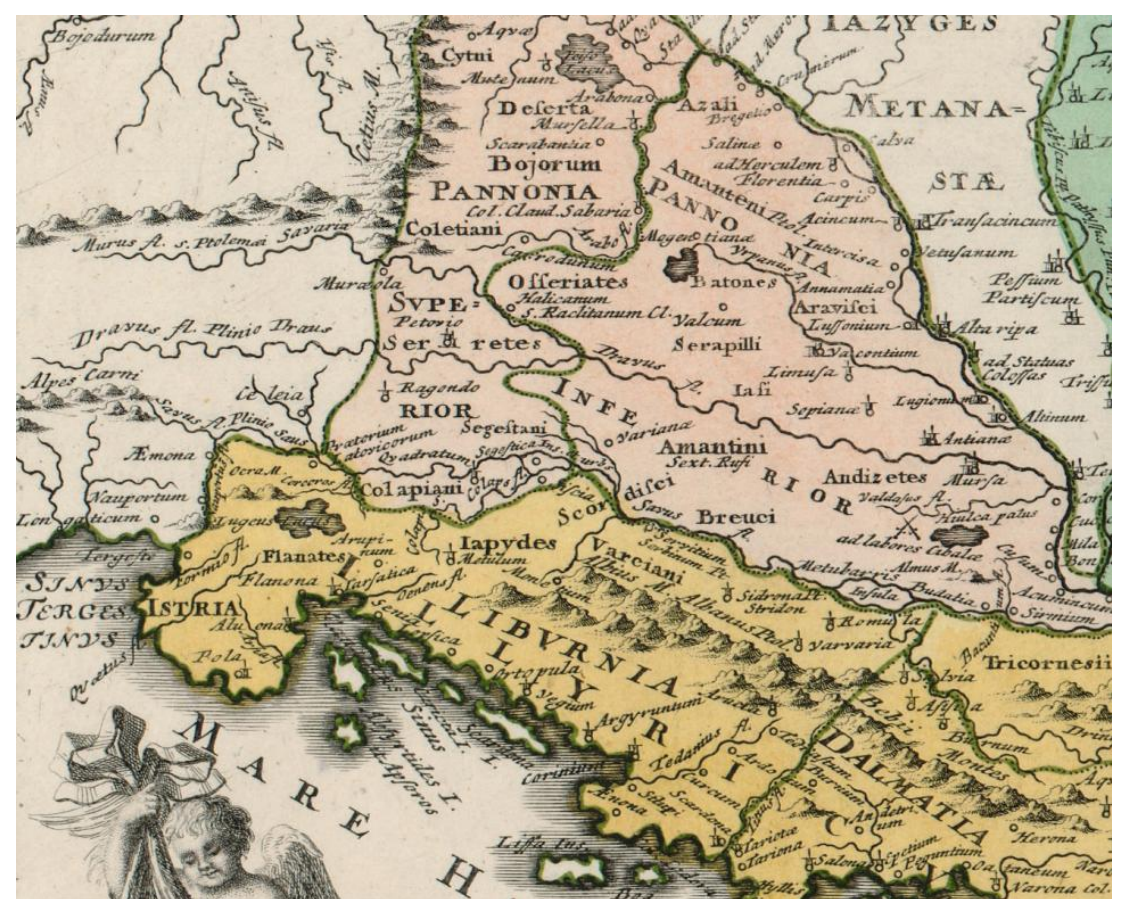

Fig. 13 Representation of Upper and Lower Pannonia in red (Christoph Weigl: Regiones Danubianae, Pannoniae, Dacia, Moesiae cum Vicino Illyrico, 1720, detail).

Slika 13. Prikaz Gornje i Donje Panonije obojene crvenom bojom (Christoph Weigl: Regiones Danubianae, Pannoniae, Dacia, Moesiae cum Vicino Illyrico, 1720, isječak).

labelled ad labores Cibalae ('at Vinkovci works'), but it is unknown which battle Weigl had in mind.

There are several different colour contrasts on this map: white, light green and light red. Light red is specific: it is also used on Weigl's 1702 map of the Habsburg-Ottoman border, and it marks the areas under the Habsburg Empire (Fürst Bjeliš 2012, 303). On this map, it appears in the description of Pannonia (Pannonia superior, Pannonia inferior; Figure 13). Colours were very important in cartography, since the great powers used them to denote their right to possess certain territories, while boundaries, as the most prominent map element, highlighted those rights. However, the problem here is that the colours on this map do not represent actual territorial holdings, but only the fact that the Croatian lands belonged to the former Roman Empire, while the entire map was modelled on the situation in the Balkan countries during the expedition of Emperor Trajan to Dacia in the 2nd century (Matijašić 2009, 222-224). If we compare this with the time when Weigl was creating the map, the light red markings extend to the Sava tributary of the Danube, where the Croatian border was formed after the Peace of Požarevac in 1718 (Valentić et al. 2005, 235). The Danube is the most prominent river and has two names - Danubius in the area of present-day Austria (Figure 14) and
Ister in the Dacia area, present-day Romania (Figure 15). In the classical and early medieval periods, the latter name of the river was often confused with Istria (for example, the Periplus of Pseudo-Scylax mentioned a connection between Istria and the Black Sea and their mutual proximity, and this was adopted by later authors such as Theopompus, Pseudo-Scymnus and Strabo (Matijašić 2009, 67). On this map there is no such confusion; Istria is marked by the normal Latin term Istria, without any reference to the River Ister (Danube) (Figure 16). Weigl must have been familiar with the old name, otherwise he would not have used it.

It should also be pointed out that Weigl made an oversight while mapping the southern border at the River Una by not marking it in red, but yellow (Figure 15). This part of the Croatian lands reverted to the Habsburg Monarchy according to the peace treaty of Srijemski Karlovci in 1699 (Valentić et al. 2005, 147) and therefore it should have been marked red, since the map was created some twenty years after the treaty. Weigl might have been influenced here by the institution of the Military Frontier which took over most of the Croatian lands after the liberation from the Ottomans. However, he did something even more interesting - he marked the areas of southern Slavonia which were also part of

KiG No. 33, Vol. 19, 2020, https://doi.org/10.32909/kg.19.33.2 - - 
je Glavač bio upućen u povijesni razvoj Dalmacije koja se $u$ antici prostirala od rijeke Raše do Lješa u današnjoj Albaniji, pri čemu se njezina istočna granica nalazila pored izvora rijeke (Matijašić 2009, 185), što odgovara smještaju njezinog grba na spomenuto područje.

Što se tiče načina pisanja toponima, oni se pišu po podvojenom principu: značajnija mjesta pišu se po latinskoj, a manje značajna po hrvatskoj verziji (Marković 1993, 194). Razlog za takvu Glavačevu odluku vrlo je jednostavan - latinski je jezik bio najrašireniji jezik tadašnje Europe, a osim većih mjesta Glavač je na latinskom zabilježio i neke važnije bitke Hrvata protiv Osmanlija. Od svih mjesta posebice se ističe Zagreb koji je izrazito precizno smješten na području između Medvednice i rijeke Save (slika 11), ali je zanimljivo kako je njegovo ime slabije istaknuto od imena mjesta na području današnjeg Hrvatskog zagorja. Također su istaknuta i mjesta pored kojih su se odigrale značajne bitke s Osmanlijama, primjerice Petrinja (slika 12). Takav potez ne može se povezati s Harleyjevim potkopavanjem socijalnih struktura koje karta inače prikazuje ispod apstraktnih instrumenata kao što su mjerila ili koordinatne mreže (Harley 1989, 5), budući da je karta imala prvenstveno vojnu, odnosno geostratešku namjenu (Marković 1993, 186) te se na njoj ne nalaze elementi koji bi upućivali na hijerarhizaciju društva koje ona prikazuje (Harley 1989, 6).

\section{Propagandni elementi na karti J. C. Weigla}

Weiglova karta, nastala 1720 . godine, po svojem geografskom opsegu obuhvaća još veći prostor od Duvalove - naime u njezin su sastav uključeni Podunavlje, Panonija, Moezija, Dacija, Tracija te Makedonija i Tesalija. ${ }^{7}$ Hrvatske su zemlje dosta nezgrapno prikazane te se stječe dojam da su one stiješnjene u odnosu na prethodno spomenute zemlje. Toponomastika je koncentriranija na područje južne Dalmacije, dok su sjeverni dijelovi rijetko obilježeni. Također je zanimljivo da nema prikaza planina na području Gorskog kotara, Istre, Primorja, Like i Dalmatinske zagore, dok je područje Bosne prikazano tek djelomično točno. Nema čak ni topografskog prikaza Zagreba, dok se rijeka Sava prikazuje kao Plinijeva Sava (Savus A. Plinio). Iznad Siska ona je prikazana kao Quadramtum Segestica ins. et urbs. Međutim, kod Vinkovaca se može vidjeti prikaz bitke u

\footnotetext{
${ }^{7}$ Izvor: Regiones Danubianae, Pannoniae, Dacia, Moesiae cum Vicino Illyrico, bakrorez, koloriran; $39 \times 31 \mathrm{~cm}$. [Mjerilo neodređeno], Christoph Weigelii. Norimbergae : Christoph Weigelii, [1720]. Nacionalna i sveučilišna knjižnica u Zagrebu.
}

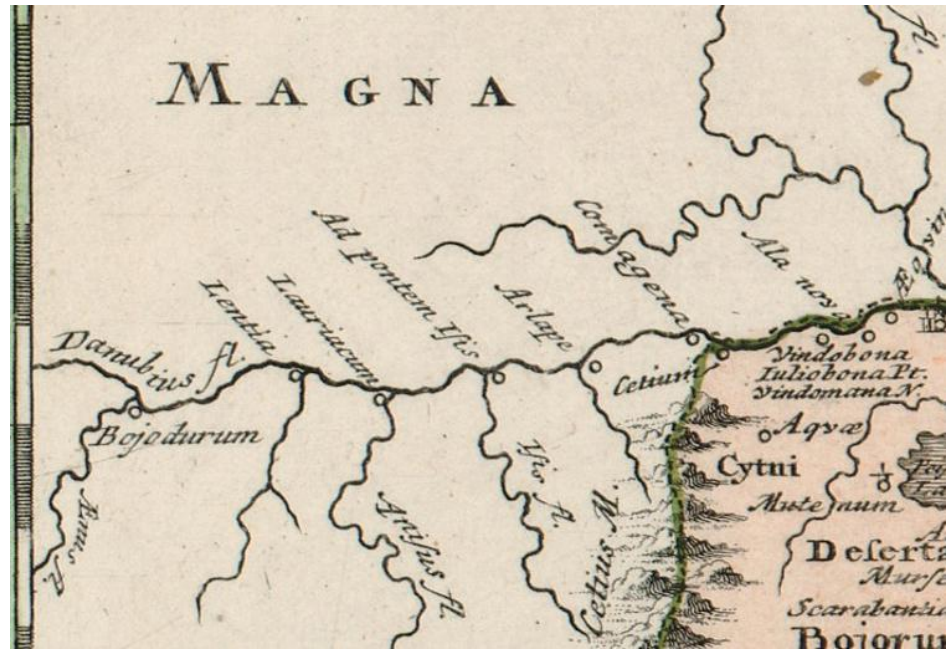

Slika 14. Rijeka Dunav u toku kroz Austriju s današnjim imenom (Christoph Weigl: Regiones Danubianae, Pannoniae, Dacia, Moesiae cum Vicino Illyrico, 1720, isječak).

Fig. 14 The River Danube flowing through Austria with its present name (Christoph Weigl: Regiones Danubianae, Pannoniae, Dacia, Moesiae cum Vicino Illyrico, 1720, detail).

obliku dva ukrštena crna mača, označen kao ad labores Cibalae, ali je nepoznato na što je točno Weigel mislio.

Kontrasti boja na toj su karti različiti; od bijele, svjetlozelene do svjetlocrvene. Potonja je boja specifična budući da se osim na ovoj javlja još i na Weiglovoj karti habsburško-osmanske granice iz 1702. godine te su njome označeni krajevi pod habsburškom vlašću (Fürst Bjeliš 2012, 303). Njome je ovdje prikazana Panonija (slika 13). Međutim, problem je u tome da boje na ovoj karti ne označavaju teritorijalnu pripadnost, već samo pripadnost hrvatskih zemalja bivšem Rimskom Carstvu, dok je cjelokupna karta rađena po uzoru na stanje balkanskih zemalja u doba ekspedicije cara Trajana u Daciju tijekom 2. st. (Matijašić 2009, 222-224). Ako se povuče paralela s vremenom $u$ kojem je Weigl stvarao tu kartu, onda označavanje spomenutih krajeva svjetlocrvenom bojom svakako ide u prilog Weiglu budući da se ta boja prostire do pritoka Save u Dunav, gdje su hrvatske granice izbile nakon Požarevačkog mira 1718. (Valentić i dr. 2005, 235). Upravo je Dunav najistaknutiji od svih rijeka te nosi oba imena - Danubius na području današnje Austrije (slika 14) te Ister na području Dacije, odnosno današnje Rumunjske (slika 15). Ta imena često su stvarala konfuziju s Istrom, čemu je najveći doprinos dao Pseudo-Skilakov periplus u kojem se spominje povezanost Istre s Crnim morem i njihova bliska međusobna udaljenost, što su prenijeli i kasniji autori kao primjerice Teopomp, Pseudo-Skimno i Strabon (Matijašić 2009, 67). Na ovoj karti nema spomenute zabune; Istra je označena normalnim latinskim terminom Istria, dakle bez ikakvog referiranja na rijeku Ister (slika 16), a 
the Military Frontier in red, the colour for mapping the imperial areas. The reason may lie in the military situation in the 18th century, when the Habsburg Monarchy conducted several anti-Ottoman offensives along the Sava and Una and so reached northern Bosnia. However, the prominent army general Eugene of Savoy died in action and the tide turned in favour of the Ottomans, who inflicted a series of defeats on the Habsburgs. According to the 1739 Treaty of Belgrade, they were forced to abandon all previously conquered areas in the Sava and Una basins. By drawing a line between Upper Pannonia and Liburnia, Weigl obviously wanted to show that the border between the Military Frontier (the Habsburg Monarchy and the Ottoman Empire) was not yet clearly defined and that the danger of reoccupation of was still present.

Weigl did not include Austria either in the Habsburg Monarchy, though it was the foundation of the entire monarchy. Instead, he marked it on his map as part of Greater Germany (Germania Magna; Figure 17). The name was obviously used to cover the social and economic dispersal in the German lands created after the centres of trade shifted from the Mediterranean to the Atlantic coast in the 16th century, exacerbated by great losses during the Thirty Years War (The Times 1989, 190). Austria remained stable, thanks to Habsburg rule in many European countries, though this was jeopardized during the 18th century owing to the rise of Prussia, which collapsed during the Napoleonic conquests of 1806. The PanGerman movement first appeared at that time, but only took off during the coalition war against Napoleon, ${ }^{8}$ a century after the creation of this map. A few years later, Germany was to reject Pan-Germanism in favour of confederation after its victory over the Habsburg army near Hradec Králové in 1866. The Habsburg Emperor Franz Joseph I turned to the Hungarian leader Ferenc Deák to broker an AustroHungarian agreement. Weigl obviously followed political developments in the German countries and Habsburg Monarchy, and his fascination made him present Austria as part of Germany. Weigl's map, in contrast to the other two, gives a first-century territorial overview of southeast Europe. However, it contains hidden messages indicating that it was created in the 18th century, along with embedded contemporary details.

\footnotetext{
8 Source:,Pan-Germanism“. Encyclopaedia Britannica. $<$ https://www.britannica.com/event/Pan-Germanism> (accessed 21 Jul 2018).
}

\section{Conclusion}

Propaganda has always been present in cartography. It has been used as a means of drawing a clear distinction between different cultures or civilisations. In this study, all three maps show how cartography as a science often conceals certain pieces of information. Duval's map shows liberated areas as well as those under Ottoman rule. It is a clear example of propaganda in cartography, with a clear demarcation line between the European ('us') and the Ottoman ('them') domains. The map also shows parts of countries not mentioned in the title (Serbia and Albania), but treats them differently. Serbia is not shown as belonging to the Ottoman empire, while Albania is given a reduced version of its coatof-arms with the image of a crescent and a star. Not all countries are mentioned on this map, (for example, the Dubrovnik Republic), probably because they were politically unimportant to the European powers of that time, such as France or the Habsburg Monarchy.

Only Glavač's map shows the unaffected parts of the Croatian lands, while its content is of much greater range. This is not the case with the first map, since it focuses exclusively on the European, while ignoring the existence of Ottoman domain. The propaganda element emerges in the depiction of coats-of arms showing which territories belonged to which geopolitical units. The Croatian coat-of-arms is placed next to the Kordun area of Steničnjak, where the last Croatian Parliament session south of the River Sava was held in 1566. There is also a great deal of information related to major and minor battles between the Croatians and the Ottomans, which are also elements of propaganda, more verbal than pictorial, like the battle descriptions. Simply put, this map has a propaganda approach which glorifies self while ignoring the other.

Weigl's map, on the other hand, presents a geopolitical situation which does not correspond to the time of its creation. However, it also contains skilfully hidden elements of propaganda which provide clues about the discrepancy. Red is used, as on another map by the same author, to show that the territorial aspirations of the Roman Empire and Habsburg Monarchy coincided. Weigl's maps also show Upper and Lower Pannonia (Panonnia Superior/Inferior) as parts of the Habsburg territory marked in red. Greater Germany (Germania Magna), a political issue which troubled the Habsburg Monarchy, is not shown in relation to the Roman Empire, nor is it marked as territory to which Austria had any claims. In this case, red is not used to mark territory, which indicates that this political option was not explicitly expressed. The remaining map information refers

KiG No. 33, Vol. 19, 2020, https://doi.org/10.32909/kg.19.33.2 - - 


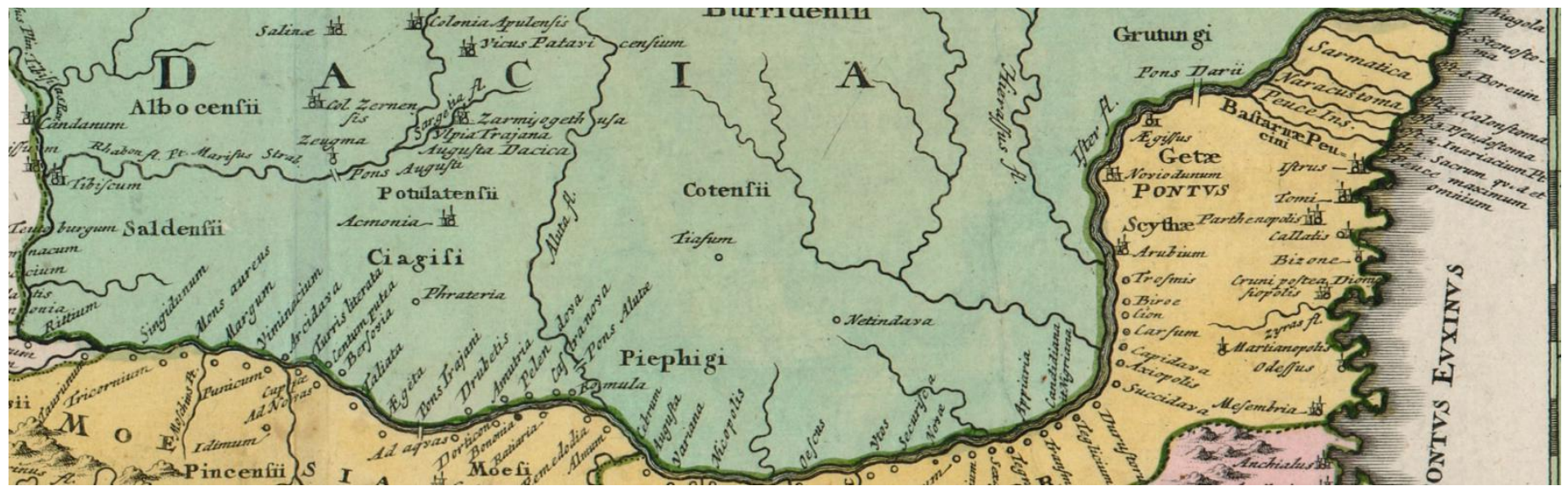

Slika 15. Donji krak Dunava nazvan antičkim imenom Ister (Christoph Weigl: Regiones Danubianae, Pannoniae, Dacia, Moesiae cum Vicino Illyrico, 1720, isječak).

Fig. 15 Lower branch of the Danube with its ancient name, Ister (Christoph Weigl: Regiones Danubianae, Pannoniae, Dacia, Moesiae cum Vicino Illyrico, 1720, detail).

što se tiče dvostrukog imenovanja Dunava, Weigl je morao biti upoznat sa starim imenom rijeke, inače ga ne bi naveo.

Također valja istaknuti da je Weigl napravio propust kod kartiranja južne granice prema Uni ne označivši je crvenom već žutom bojom (slika 15). Naime, spomenuti dio hrvatskih zemalja vraćen je u okrilje Habsburške Monarhije još mirom u Srijemskim Karlovcima 1699. godine (Valentić i dr. 2005, 147) te bi stoga trebao biti prikazan crvenom bojom s obzirom na to da je karta nastala dvadesetak godina nakon spomenutog mira. Weigl se najvjerojatnije poveo za institucijom Vojne krajine koja je ubrzo nakon oslobađanja hrvatskih zemalja od Osmanlija većinu njih podredila svojoj vlasti, ali je pri tome učinio još zanimljiviju stvar - područja južne Slavonije označio je crvenom bojom koju je koristio za kartiranje carskih prostora. Razlog takvog kartiranja leži u ratnim okolnostima 18. st. Naime, Habsburška Monarhija u 18. je stoljeću povela nekoliko protuosmanskih ofenziva uzduž Save i Une te je tako dospjela do sjeverne Bosne, međutim tijekom rata umire vojskovođa Eugen Savojski te se ratna sreća okreće u korist Osmanskog Carstva, što rezultira Beogradskim mirom iz 1739. godine kojim su Habsburzi morali napustiti sva prethodno osvojena područja u Posavini i Pounju. Povlačenjem linije između Gornje Panonije i Liburnije Weigl je htio pokazati kako je granica između Vojne krajine, odnosno Habsburške Monarhije i Osmanskog Carstva, s obzirom na ratne okolnosti, još uvijek nejasno definirana.

Osim Pounja, Weigl nije u sastav Habsburške Monarhije uključio ni Austriju koja je na ovoj karti označena kao dio tzv. Velike Njemačke (Germania Magna; slika 17). Spomenuti naziv najvjerojatnije je upotrijebljen kako bi se prikrio društveni i ekonomski rasap u njemačkim zemljama nastao nakon premještanja trgovačkih središta s Mediterana na atlantske obale u 16. st., čemu su dodatno pridonijeli veliki gubitci nastali tijekom Tridesetogodišnjeg rata (The Times 1989, 190). Najstabilnija među njima bila je upravo Austrija upravo zahvaljujući habsburškoj vlasti u velikom dijelu europskih zemalja koja je tijekom 18. st. došla pod ugrozu zahvaljujući usponu Pruske. Spomenuti je naziv poveziv s pokretom pangermanizma, koji se tada počeo javljati, ali on je zaživio tek za vrijeme rata koalicije protiv Napoleona ${ }^{8}$, puno stoljeće nakon nastanka ove karte. Iz navedenog se može zaključiti kako je Weigl pratio političke procese u njemačkim zemljama i Habsburškoj Monarhiji te ga je fascinacija istima natjerala da Habsburšku Monarhiju, odnosno Austriju, prikaže kao dio Njemačke. Također se može reći kako je ova karta, za razliku od prethodne dvije, specifična po tome što prikazuje teritorijalni pregled zemalja jugoistočne Europe iz 1. st., ali se na njoj opet nalaze skrivene poruke koje upućuju da je karta rađena $u$ 18. st. te da su poneke informacije iz spomenutog vremena ucijepljene u nju.

\section{Zaključak}

Propaganda je oduvijek bila prisutna u kartografiji. Korištena je kao način da se jasno napravi razlika između različitih kultura ili civilizacija. U ovme radu sve tri karte pokazuju kako kartografija kao znanost često prikriva određene podatke. Duvalova karta prikazuje

\footnotetext{
8 Izvor: „Pan-Germanism“. Encyclopaedia Britannica. https:// www.britannica.com/event/Pan-Germanism (pristupljeno 21. VII. 2018.).
} 


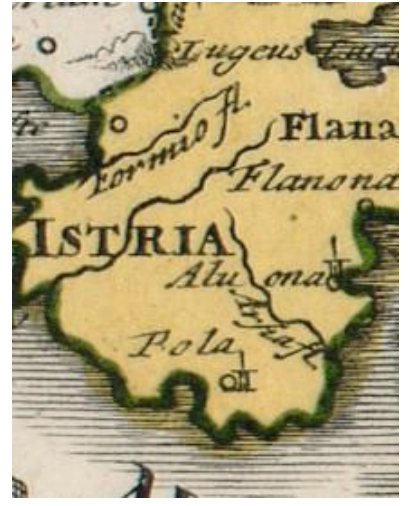

Fig. 16 Representation of Istria without reference to the Danube (Ister) (Christoph Weigl: Regiones Danubianae,

Pannoniae, Dacia, Moesiae cum Vicino Illyrico, 1720, detail).

Slika 16. Prikaz Istre bez referiranja na Dunav (Ister)

(Christoph Weigl: Regiones Danubianae, Pannoniae, Dacia, Moesiae cum Vicino Illyrico, 1720, isječak).

to weather conditions, and there is no other hidden propaganda.

Despite their differences, all three sources are proof that propaganda is present in cartography. However, not all discrepancies should be interpreted exclusively as propaganda. A detailed analysis is necessary, taking into consideration the circumstances in which the maps were created and the authors' knowledge of the mapped area. Cartographic sources are not mere pieces of paper which represent certain territories, but also convey hidden or explicit propaganda messages, reflecting the advantages and disadvantages of the author's trade, and his personal attributes and opinions.

\section{Sources and Atlases}

Les confins des chrestiens et des Turcs en terre ferme, c'est-à-dire la Hongrie l'Esclavonie, la Croatie et la Dalmatie / par P. [Pierre] Du Val, Paris: Pierre DuVal, 1663, chalcography, colored; $37 \times 50 \mathrm{~cm}$ [scale 1:1 300 000] National and University Library in Zagreb

Nova hactenus editarum mendis expurgatis ac multis quae omissa erant additis accurate concinnata partium Regni Sclavoniae et Croatiae a Christianitate etiamnum possessarum confiniumque descriptio, per Stephanum Glavach. Varasdiensem, 1673, copy; $83 \times 81 \mathrm{~cm}$, folded to $23 \times 32 \mathrm{~cm}$ [scale: c. 1:250 000], National and University Library in Zagreb

Regiones Danubianae, Pannoniae, Dacia, Moesiae cum Vicino Illyrico. chalcography, colored; $39 \times 31 \mathrm{~cm}$. [scale unspecified], Christoph Weigelii. Norimbergae :Christoph Weigelii, [1720], National and University Library in Zagreb

The Times. Atlas svjetske povijesti. Ljubljana: Cankarjeva založba. 1989

\section{References / Literatura}

Boria E (2008) Geopolitical Maps: A Sketch History of a Neglected Trend in Cartography. Geopolitics vol. 3, no. 2, 278-308. doi: $10.1080 / 14650040801991522$

Brković I, Mlinarić D (2013) Reprezentacija Dubrovnika u književnosti i kartografiji 17. stoljeća. Književna istorija: časopis za nauku o književnosti, vol. 45, no. 149, 29-53

Crampton J W (2001) Maps as social constructions: power, communication and visualization. Progress in Human Geography, vol. 25, no. 2, 235-252. doi: 10.1191/030913201678580494

Crampton J W (2009) Cartography: performative, participatory, political. Progress in Human Geography, vol. 33, no. 6, 840-848. doi: 10.1177/0309132508105000

Fürst-Bjeliš B, Zupanc I (2007) Images of the Croatian Borderlands: Selected Examples of Early Modern Cartography. Hrvatski geografski glasnik, vol. 69, no. 1, 7-23. doi: 10.21861/HGG.2007.69.01.01

Fuerst Bjeliš, B (2012) „Imaging the Past: Cartography and Multicultural Realities of Croatian Borderlands“, Intech: Open Science, Open Minds, 2012, 296. https://www.intechopen.com/books/cartography-a-tool-for-spatial-analysis/imaging-the-pastcartography-and-multicultural-realities-of-croatian-borderlands (pristupljeno 30. III. 2018)

Harley J B (1988) Maps, knowledge and power. In: The Iconography of Landscape. Essays on the symbolic represntation, design and use of past environments, Cosgrove, Denis; Daniels, Stephen (eds.) Cambridge University Press. Cambridge, 277-312

Harley J B (1989) Historical geography and the cartographic illusion. Journal of Historical Geography, vol 15, 80-91. doi: $10.1016 /$ S0305-7488(89)80066-0

Jowett G S, O'Donnell V (2006) Propaganda and Persuasion (fourth edition). Sage Publications Inc., Thousand Oaks

Marković M (1993) Descriptio Croatiae, Naprijed, Zagreb

Matijašić R (2009) Povijest hrvatskih zemalja u antici do cara Dioklecijana, Leykam International

Mlinarić D, Gregurović S (2011) Kartografska vizualizacija Drugoga na primjeru višestruko graničnih prostora. Migracijske i etničke teme, vol. 27, no. 3, 345-373. doi: 10.11567/met

Valentić M, Čoralić L, Mirošević F, Velagić Z (2005) Povijest Hrvata. Druga knjiga. Od kraja 15. stoljeća do kraja Prvoga svjetskog rata, Školska knjiga, Zagreb 
oslobođena područja kao i ona pod osmanskom vlašću. To je jasan primjer propagande $u$ kartografiji, s jasnom razgraničenom linijom između europskog $\left(, \mathrm{mi}^{\prime \prime}\right)$ i osmanskog (,oni“) područja. Na karti su prikazani i dijelovi zemalja koji nisu navedeni u naslovu (Srbija i Albanija), ali su različito tretirani. Srbija nije prikazana kao pripadnica Osmanskoga Carstva, dok Albaniji daje umanjenu verziju grba sa slikom polumjeseca i zvijezde. Nisu sve zemlje spomenute na toj karti (npr. Dubrovačka Republika), vjerojatno zato što su bile politički nevažne europskim silama toga vremena, poput Francuske ili Habsburške Monarhije.

Samo Glavačeva karta prikazuje neosvojene dijelove hrvatskih zemalja, dok je njezin sadržaj znatno većeg raspona. To nije slučaj s prvom kartom kojoj je u fokusu isključivo područje Europe, zanemarujući postojanje osmanskog područja. Element propagande pojavljuje se u prikazu grbova koji prikazuju koja su područja pripadala kojim geopolitičkim jedinicama. Hrvatski grb postavljen je uz kordunski kraj Steničnjak, gdje je 1566. održana posljednja sjednica Hrvatskoga sabora južno od rijeke Save. Također postoji puno informacija koje se odnose na velike i manje bitke između Hrvata i Osmanlija, koje su ujedno i elementi propagande, više verbalni nego slikovni, poput opisa bitke. Jednostavno rečeno, ova mapa ima propagandni pristup koji veliča sebe dok ignorira druge.

Weiglova karta, s druge strane, prikazuje geopolitičku situaciju koja ne odgovara vremenu nastanka. Međutim, ona također sadrži vješto skrivene elemente propagande koji daju tragove proturječja. Crvena boja se koristi, kao i na drugoj karti istog autora, kako bi pokazao da su se teritorijalne težnje Rimskoga Carstva i Habsburške Monarhije podudarale. Weiglove karte također prikazuju Gornju i Donju Panoniju ( $\mathrm{Pa}-$ nonnia Superior/Inferior) kao dijelove teritorija Habsburga označene crvenom bojom. Velika Njemačka (Germania Magna), političko pitanje koje je uznemirilo Habsburšku Monarhiju, nije prikazano u odnosu na Rimsko Carstvo, niti je označeno kao teritorij na koji je Austrija imala bilo kakvih zahtjeva. U ovom se slučaju crvena boja ne koristi za označavanje teritorija, što ukazuje da ta politička opcija nije bila izričito izražena. Preostale informacije na karti odnose se na vremenske uvjete, a druge skrivene propagande nema.

Unatoč njihovim razlikama, sva su tri izvora dokaz da je u kartografiji prisutna propaganda. Međutim, ne treba sve interpretacije protumačiti isključivo kao propagandu. Potrebna je detaljna analiza uzimajući u obzir okolnosti u kojima su karte nastale i autorovo poznavanje kartiranog područja. Kartografski izvori nisu puki komadi papira koji predstavljaju određene teritorije,

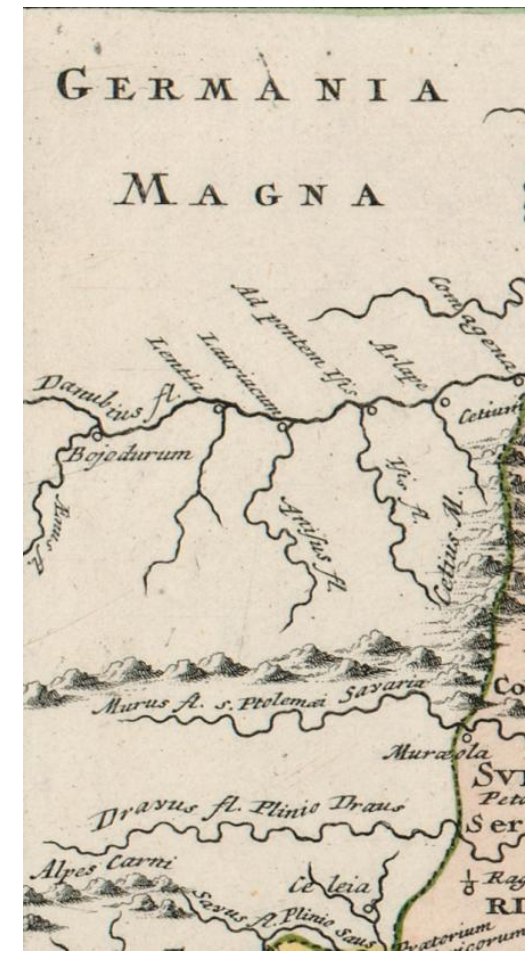

Slika 17. Habsburška monarhija prikazana kao dio Velike Njemačke (Christoph Weigl: Regiones Danubianae,

Pannoniae, Dacia, Moesiae cum Vicino Illyrico, 1720, isječak).

Fig. 17 The Habsburg Monarchy shown as part of Greater Germany (Christoph Weigl: Regiones Danubianae, Pannoniae, Dacia, Moesiae cum Vicino Illyrico, 1720, detail).

već prenose skrivene ili eksplicitne propagandne poruke, koje odražavaju prednosti i nedostatke autorove vještine, ali i njegove osobne karakteristike i mišljenja.

\section{Izvori i atlasi}

Les confins des chrestiens et des Turcs en terre ferme, c'est-à-dire la Hongrie l'Esclavonie, la Croatie et la Dalmatie / par P. [Pierre] Du Val, Paris: Pierre DuVal, 1663., bakrorez, koloriran; $37 \times 50 \mathrm{~cm}$ [mjerilo 1:1 300 000] Nacionalna i sveučilišna knjižnica u Zagrebu

Nova hactenus editarum mendis expurgatis ac multis quae omissa erant additis accurate concinnata partium Regni Sclavoniae et Croatiae a Christianitate etiamnum possessarum confiniumque descriptio, per Stephanum Glavach. Varasdiensem, 1673, kopija; $83 \times 81 \mathrm{~cm}$, presavijena na $23 \times 32 \mathrm{~cm}$. [mjerilo: oko 1:250 000], Nacionalna i sveučilišna knjižnica u Zagrebu

Regiones Danubianae, Pannoniae, Dacia, Moesiae cum Vicino Illyrico. bakrorez, koloriran; $39 \times 31 \mathrm{~cm}$. [mjerilo neodređeno], Christoph Weigelii. Norimbergae : Christoph Weigelii, [1720] Nacionalna i sveučilišna knjižnica u Zagrebu

The Times. Atlas svjetske povijesti. Ljubljana: Cankarjeva založba. 1989. 